\title{
The Role and Challenge of Ethiopian Commodity Exchange (ECX) on Coffee Supplies and Marketing in Ethiopia
}

\author{
Seyfe Fikre \\ Correspondence: Seyfe Fikre, College of Business and Economics, Department of Economics, Bonga University, \\ P.O.Box: 334, Bonga, Ethiopia.
}

Received: August 20, 2020

doi:10.11114/bms.v6i3.4976

\author{
Accepted: September 7, 2020 \\ Online Published: September 9, 2020 \\ URL: https://doi.org/10.11114/bms.v6i3.4976
}

\begin{abstract}
The objective of the study was to examine the role and challenge of ECX in coffee supply by measuring the core function ECX. The study used primary data collected from 120 respondents and analyzed through descriptive statistics and multiple linear regression. The study used six core function of ECX i.e. market information, enabling competition, market development, price discovery, and storage and grading and facilitation of physical commodity to measure the role and challenge of ECX. The results of the descriptive statistics showed that among ECX's core function, facilitation of physical commodity trade service was given the highest score while the storage and grading service was given the least score by the respondents. The multiple linear regression result indicate that three independent variable (Market information, market development and facilitation of physical commodity trade) were found to be significantly and positively influence the coffee supply and performance. Facilitation of physical commodity trade was significant at $1 \%$ while market information and market development were significant at $10 \%$. Even though ECX have contributed to coffee supply and marketing performance, it is not free from a problem. The challenge are associated with service delivery system like grading system to test the quality of coffee was not uniform and biasedness one client from the other and wastage of time to test and low quality grading widely observed. ECX experts also indicate that absence of skilled man power, low government attention and capital shortage also another challenge in coffee marketing and supply. ECX should improve the service of storage and grading by introducing new technology and by maintaining transparent service. ECX should also build better warehouse management system in order to avoid wastage and quality deterioration.
\end{abstract}

Keywords: Ethiopian commodity exchange, coffee supply and marketing, multiple linear regression

\section{Introduction}

Coffee is one of the most important agricultural commodities in Ethiopia due its historical economic, social and cultural importance in the country. According to the Ministry of Trade (MoT) of Ethiopia, the country produced an average of 300 thousand tons of coffee per year between 2000 through 2012. It is also responsible for the livelihoods of an estimated 1.3 million producers and 15 million people between producers, wage workers, transporters and their families (Fetene, 2019).

In the era of globalization, how the economy and commodity market exchange is organized and coordinated is increasingly became a fundamental concern of all nations across the world (Gebrekiros, 2011). More specifically, linking of buyers and sellers in to commodity market for the effective and efficient accomplishment of transactions among the participants is the most challenging task. In response to this and following market liberalization and increasingly affordable information technology since 1990, commodity exchanges have mushroomed around the world.

Commodity exchanges are organized markets which serve as a means for risk management and transaction costs reduction for both buyers and sellers (Rashid, 2015). Historically, commodity exchanges date back to the middle ages. Until recently, commodity exchanges were strictly confined to industrialized countries, but with the advent of affordable technology many developing countries in Africa have been keen on establishing one. The wave began in the 1990s, starting with Zambia and Zimbabwe and followed by Kenya and Uganda. The most recent one to join the group of exchanges in Africa was the Ethiopian Commodity Exchange established in 2008(Tsega , 2010).

The Ethiopian Commodity Exchange was established in 2008 to revolutionize Ethiopian agriculture and transform the economy through a dynamic, efficient and transparent marketing system that serves all and essentially turns commodity 
into assets. And properly implemented and regulated, commodity exchanges can contribute greatly to the achievement of country's economic and developmental goals and strengthen the bargaining power of weak groups such as small farmers (Tsega, 2010). ECX has begun its operation by only offering spot trading and with a legal mandate to launch futures contract transactions (ECX, 2008, Abdurezack, 2010).

The ECX serves as a central marketplace where trade is carried out through a single, well-defined marketing mechanism (ECX, 2008). The scope of the ECX is to promote the commercialization of major agricultural commodities, such as grains, pulses and coffee. In its wider sense, a commodity exchange is any organized marketplace where trade is transact through a single, well-defined marketing mechanism (Eleni, 2005). Agricultural markets in Ethiopia have long been exposed to high transaction costs, price fluctuations and excessive risk ( Rashid et al., 2010).

Ethiopian commodity exchange (ECX) signifies a major advancement in the development of the Ethiopian agro-commodity market to promote the commercialization of major agricultural commodities. The study on hand base for analysis on the coffee sector because coffee is a major export commodity and an important source of employment in Ethiopia (Tsega, 2010). Coffee is also the most traded agricultural commodity in the ECX both in terms of volume and value, and significant reforms have occurred in the coffee sector in the past years.

Since Ethiopian commodity exchange established in 2008, it has been decisive role in enhancing the performance commodity exchange. Providing appropriate market information has paramount role to sustain increased production and improve the livelihood of smallholder farmers. Hence, having integrated marketing information system in a particular country plays decisive role in enhancing the performance of commodity exchange (Eleni, 2005).

Marketing is critical for coffee to be successful in today's competitive business environment (Alemayehu, 2014). The ECX is believed to provide market integrity, efficiency, transparency, and risk management and thereby revolutionize the coffee market. However, to live up to its expectations, identifying the opportunities and challenges of Ethiopian commodity exchange on coffee supplies and marketing and designing a practical risk management system is an absolute necessity.

Researches regarding to the role of Ethiopian commodity exchange participants are very limited and the challenges of the participants is not fully articulated and described yet. The previous study focuses on the challenge and the role of ECX separately. For instance, Mulugeta (2008), Betelehem(2009), Desselaw(2011), GebreKiros(2011) and Mohammed (2015) identify the challenge of ECX. According to their finding liquidity, weak physical and communication infrastructure, a lack of legal and regulatory environments, and risk management problem are the main challenges of ECX. Even though, their finding was have its own contribution, they didn't consider the other challenge of ECX in relation to storage and grading, price discovery and information.

On the other hand the study by Tewabe(2015), Muluken(2016), Ana (2018), Bizulem (2018) and Meskerem (2018), Sisay(2019) studied the role and contribution of ECX in relation to market efficiency, warehouse service, laboratory test, grading, trading platform/auction service, provision of communication using descriptive statistics. Their studies didn't consider the challenge when ECX provide the above identified contribution.

Assessing the contribution of ECX in line with the challenge faced together would be important for better market development. In addition, the previous study didn't address the role and challenge of ECX specifically with coffee supply and marketing. Therefore, the study on hand considers the role and challenge of ECX in coffee supply and market using the appropriate regression analysis. Even though ECX have been provide priceless role in commodity market, the literature on its contribution and challenge is limited especially in coffee supply and market. Therefore the study were the analyzed role and challenge of the Ethiopian commodity exchange participants, small holder farmers and overall performance of ECX its contribution and associated challenges especially in relation with coffee supply and marketing.

This study was aimed to answer the following basic research questions:

1. Does the ECX client satisfy with the core function of ECX?

2. What is the contribution of ECX on coffee supplies and marketing?

3. What are significant challenges that affect in coffee market actors?

\section{Literature Review}

Mulugeta (2008) have studied the challenge and prospects of liquidity on ECX, and he find that the situation of sharply rise of domestic and global market price, The high dependence of Ethiopian Agriculture on the rainfall condition which might create shortages of supply in case of drought, The frequent rejection of commodities due to failure to meet the quality standards and the tendency to use outdated closing price as reference price to determine price limits are the main challenge of ECX. 
Betelehem (2009) tried to assess the challenge of ECX for the year of 2008 and 2009 using qualitative technique data obtained from ECX officers. Her finding indicates the lack of liquidity and current risk management of ECX did not cover adequately the scope and importance of the commodity price risk problem. Besides the risk management techniques( specially the mainly used market surveillance) fails to provide ways for assessing, monitoring, and managing the price risks faced by individual producers, producer groups, banks, trading companies, and other firms operating in commodity markets. Information dissemination, quality standards and assurances are the proposed way of escaping the problem.

Dessalaw (2011) examined the existing prospects to commodity exchange and to explore the challenges faced by the Ethiopian commodity exchange using the qualitative research approach. He finding indicate that small size of domestic commodity market, weak physical and communication infrastructure, a lack of legal and regulatory environments, and the likelihood of policy interventions are the major challenge of ECX. Investment in transport should be given priority to achieve the goals of risk management and reduced transaction costs.

The study by Gebrekiros(2011), studied about trading in Commodity Exchange and Challenges of Participants: The Case of Ethiopian Commodity Exchange using sample of 80 participant in ECX, He employed descriptive statistics and logistic regression technique and found that time of participation, limited membership seat and membership seat fee were found to be highly significant variables and were found to be the most determines factors the hinder ECX participants to participate in to the full membership category.

The study by Wendemagegn (2014) has tried to analyze coffee market chain in the case of Dale district of Southern Ethiopia. The analysis of market structure indicates that the volume of coffee traded in the area was concentrated in the hand of few traders who controlled the bigger share of the market. This clearly implies that the coffee market in the area is non-competitive. He also depicted the major entry barriers into the coffee market such that shortage of capital, licensing only for specific business activities and presence of informal traders are obstacles for most traders. He tried to disclose that the coffee marketing channel in the study area is relatively short, the existence of informal traders in both rural and urban areas discouraged the legal/licensed traders. Their also have poor access for timely and reliable market price information.

Study by Mohammed (2015) on ECX market prospect and challenge in focus by employing descriptive research method and simple linear regression using 128 sample member of ECX. His study indicate that The challenges associated with commodity marketing include the potential for market abuse, increased cost of trading, liquidity issues, quality problem and unfair competition among traders.

The study by Andersson et al (2015) indicated that the effect of warehouse access on price dispersion may not be linear, and that the downward pressure on dispersion may grow over time. They also presented an increase in the availability of adequate and timely market information should reduce search costs, while an improvement in the legal framework and reduced risk of defaults should reduce costs associated with transaction. The reduced transfer costs are likely to reduce price dispersion between exported coffees from different regions, as well as price dispersion between the export price and local retail price within regions.

Muluken et al (2016) studied the contribution of Ethiopian commodity exchange for promoting export of agricultural product using descriptive research approach for 148 sample respondent. Their results indicate that ECX provide market price information, grading the quality of goods, provide infrastructure for exporter like warehouse, electricity and telecommunication. Even though ECX provide benefit for exporter ECX has a problem in trained manpower and technology which needs improvement for a complete operation.

The study by Meskerem (2018) studied Factors Affecting the Market Efficiency of Ethiopian Commodity Exchange using sample of 185 market actor. Pearson correlation and linear regression was applied to identify the relationship among market efficiency and its determinants. The result indicates that price discovery, clearing and settlement and market data dissemination have positive impact on market efficiency.

Bizualem et al(2018) studied the role of ECX in crop value chain development in Ethiopia and indicate that ECX provide a service of warehouse service, laboratory test, grading, trading platform/auction service, provision of communication links; and market related training services for agents. Even though ECX create a more reliable way to connect buyers and sellers in an efficient way to discover market prices, a way to level the playing platform by providing market information to all, there are still problems which are faced by all actors in value chain, Such as infrastructural problems.

Similarly Mekdes (2019), studied Determinants of market efficiency of Ethiopian Commodity Exchange (ECX) for the case of Sesame trade. She employed explanatory type of research for data obtained from trader and employee in ECX. Marketing risk, marketing cost, product quality, information transmission media, transaction risk, payment method and 
market efficiency are the main determinants and direct relation with market efficiency.

The study by Sisay (2019) also studied factor affecting the market efficiency of ECX using data obtained from 170 member of ECX. He used linear regression technique for analysis and find that market information, regulation, clearing and settlement, warehouse and also trading system of the company are positively and significantly affect the market efficiency of ECX.

Fetene (2019) studied the role of ECX in stimulating agricultural commodity exports with the case of export coffee using 118 coffee exporters. He applied descriptive statistics and linear regression model to identify role of ECX. His findings of descriptive statistics of the independent variables showed that facilitation of physical trade dimension scored the highest rating with a mean value of 3.83 while the storage and grading dimension scored the least mean value of 2.86. The regression result regression analysis was also conducted, and his result indicated that storage and grading, market information provision and market development dimensions of $\mathrm{ECX}^{\mathrm{e}} \mathrm{s}$ roles had a significant positive influence on export performance of coffee exporters.

\section{Method and Material}

\subsection{Research Approach}

Quantitative research approach was used in this study. Quantitative methods involve the process of collecting, analyzing, interpreting, and writing the results of a study (Kothari, 2004). It employs strategies of inquiry such as experiments and surveys, and collects data on predetermined instruments that yield statistical data.

A survey design and questionnaire method was used to analyze the role and challenge of ECX on coffee supply and marketing. Survey research provides a quantitative or numeric description of trends, attitudes, or opinions of a population by studying a sample of that population (Fetene, 2019).

\subsection{Target Population and Sampling Procedure}

Target population of this study was the stakeholder of Ethiopian Commodity Exchange in relation with coffee marketing and supplies. These stakeholders are the coffee producer, coffee exporter, trader and ECX official are the target population of these study. The questionnaire were collected in March- April 2020. The study used coffee exporter and distributor, merchants and ECX official were the respondents in this study. The respondent were selected based on random probability sampling technique.

In this research random sampling was applied in which the number of sample was calculated using Kothari (2004) formula in case of unknown population, which helps to identify target respondents to measure their level of satisfaction. $\mathrm{n}=\mathrm{z}^{2} \mathrm{pq} / \mathrm{Q}^{2}$ Which is valid where $\mathrm{n}$ is the sample size, $\mathrm{Z2}$ is the abscissa of the normal curve that cuts off an area at the tails (1- $\alpha$ equals the desired confidence level, e.g. $95 \%$ ), $\varrho$ is the desired level of precision, $p$ is the estimated proportion of an attribute that present in the population, and $q$ is 1-p. The value for $\mathrm{Z}$ is found in statistical table, which contain the area under the normal curve. Based on sample size determination formula 120 sample were selected for this study. A structured self- completed questionnaire was prepared and distributed to the respondents.

\subsection{Data Analysis}

The data collected using structured questionnaire was edited, coded and analyzed with great care. The coding of the possible alternatives in the questionnaire was made in advance of administering the questionnaire to the respondents. That means, the possible responses were pre-coded in a five point scale ( $1=$ strongly disagree, $2=$ disagree, $3=$ indifferent, $4=$ agree, $5=$ strongly agree) to facilitate quick answering of the questions and to simplify data entry into computer software for analysis.

All the data collected using the questionnaires was coded and entered in to Statistical Package for Social Sciences (SPSS). There after both descriptive analysis (percentages and mean) and econometrics analysis was carried out by using SPSS. Multiple linear regression analysis was applied in addition to descriptive statistics for a better understanding of the challenge and contribution of ECX on coffee supply and marketing.

\subsubsection{Model Specification}

The study used coffee supplied as a dependent variable. And Based on literature and own experience, the following independent variables identified and expected to influence the dependent variables:

First price discovery (PD) through via price information on the market, second facilitation of physical trade (FPT), which indicates the market access. Third Storage and Grading (SG), which expects to capture information about coffee quality control and availability of warehouse. Forth Market Development (MD), indicate capacity building and training, international trade facilitation and improving information and technology. Finally Enabling Competition (EC) and Market information (MI) expects to influence supply performance, measured in terms of competitive market. Therefore 
the model is specified as follow: $\beta$

$\mathbf{Y}=\mathbf{f}(\mathbf{x})=\beta_{0}+\beta_{1} \mathbf{P D}+\beta_{2} \mathbf{F P T}+\beta_{3} \mathbf{S G}+\beta_{4} \mathbf{M D}+\beta_{5} \mathbf{E C}+\beta_{6} \mathbf{M I}+\mathbf{u}_{\mathbf{i}}$

Where $\mathrm{Y}$ is dependent Variable (Coffee supply and marketing performance),

$\beta_{0}, \beta_{1}, \beta_{2}, \beta_{3}, \beta_{4}, \beta_{5}, \beta_{6}$ are parameters of the model and PD,FPT,SG, MD,EC,MI are independent variable of the model indicate respectively.

Table 1. Summary of Variable description

\begin{tabular}{|c|c|c|c|}
\hline Abbreviation & Description & $\begin{array}{l}\text { Unit } \\
\text { measurement }\end{array}$ & $\begin{array}{l}\text { Expected } \\
\text { sign }\end{array}$ \\
\hline CS & supply of coffee via ECX & subjective & $\begin{array}{l}\text { Dependent } \\
\text { variable }\end{array}$ \\
\hline $\mathrm{PD}$ & $\begin{array}{l}\text { Price Discovery (prices come to reflect known information about the } \\
\text { market) }\end{array}$ & Nominal & $+\mathrm{ve}$ \\
\hline FPT & Facilitation of Physical Trade & Nominal & $+\mathrm{ve}$ \\
\hline SG & $\begin{array}{l}\text { Storage and Grading } \\
\text { (Role is performed by providing warehouse storage service and } \\
\text { grading and standardization service by the Exchange itself). }\end{array}$ & Nominal & $+\mathrm{ve}$ \\
\hline MD & $\begin{array}{l}\text { Market Development } \\
\text { (Measured using capacity building and training, international trade } \\
\text { facilitation, improving information and communication technology } \\
\text { level and introducing new products and services to meet evolving } \\
\text { needs (Fetene, 2019). }\end{array}$ & Nominal & $+\mathrm{ve}$ \\
\hline $\mathrm{EC}$ & $\begin{array}{l}\text { Enabling Competition(Measured objectively in terms of market } \\
\text { concentration) }\end{array}$ & Nominal & $+\mathrm{ve}$ \\
\hline MI & Market Information(reliable and timely market information) & Nominal & $+\mathrm{ve}$ \\
\hline
\end{tabular}

Source: Own construction, 2020

\section{Result and Discussion}

\subsection{Descriptive Statistics}

Descriptive statistics was employed to examine the mean, percentage and standard deviation of the response of respondent for the role of ECX (market information, enabling competition, market development, price discovery, storage and grading and facilitating of physical trade) on coffee supply performance. The respondent were asked to rate their perception on five point likert type scale range from 1 strongly disagree to 5 strongly agree. For simplicity purpose (1) were "strongly disagree", (2) were "disagree", 3 were categorized as "indifferent", 4 were "agree" and 5 were categorized as "strongly agree(strongly satisfied)". The mean scores have been computed for all the variables by equally weighting the mean scores of all the items under each dimension. The mean value provides the idea about the central tendency of the values of a variable. Standard deviation is to give the idea about the dispersion of the values of a variable from its mean value. The results of the descriptive analysis are shown in the table below. 
Table 2. Descriptive statistics of variables

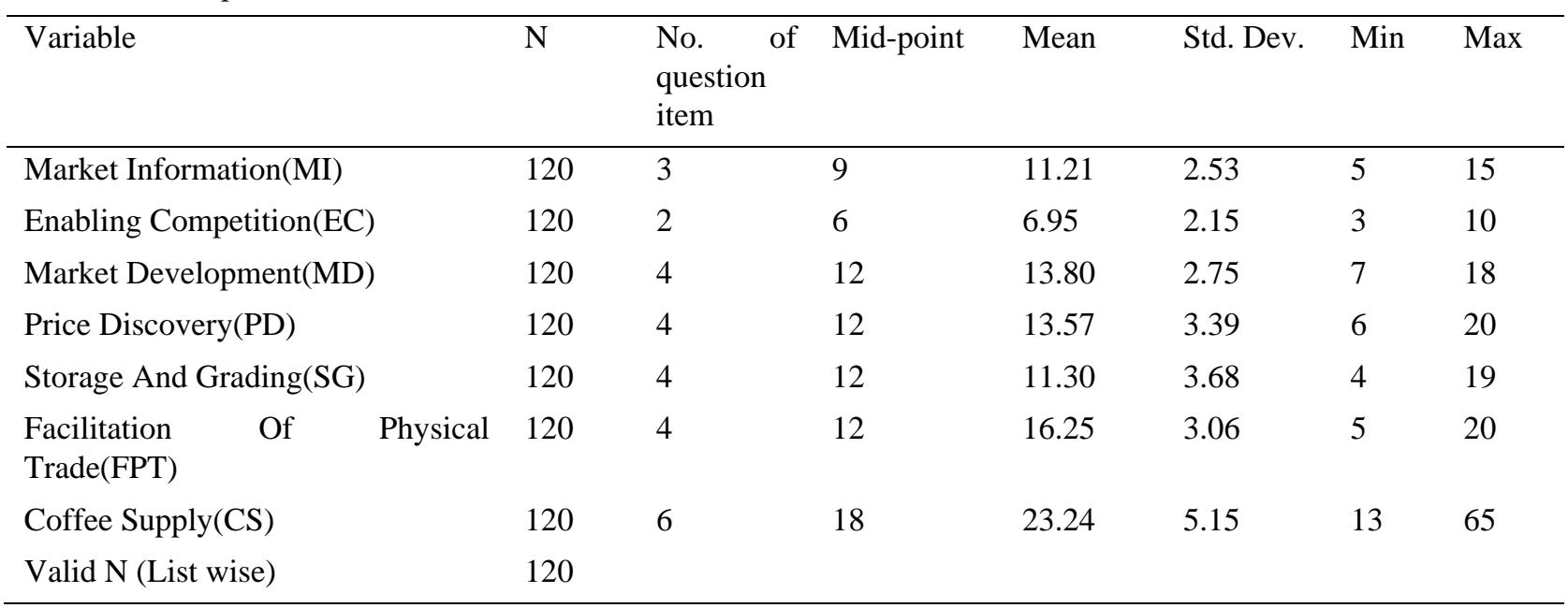

Source: survey result, 2020

The table shows that the role dimensions were considered as impact on coffee supply performance of ECX users. The mean value of the variable ranges from 6.95 (mean value of enabling competition) to 16.25 (the mean value of facilitating physical trade) with standard deviation 2.15 and 3.06 respectively. If the mean score were above the bench mark for agreement and disagreement are considered as the role of ECX attractive, but if it's below bench mark the role of ECX is not attractive.

From table 2, the mean score of storage and grading was 11.30 and its standard error was 3.68. Since the study used three elements to measure the storage and grading and the average value should be 12 at least to serve the minimum service by the ECX. This implies that, functions of ECX related to the storage \& grading were perceived to be unsatisfactory to the client.

On the other hand, the dimension of Facilitation of physical trade with the mean 16.25 and standard deviation 3.06 considered as the first important role of ECX. Since the study used 4 elements to measure this variable, the minimum average value should be 12 to provide minimum service. As rated by respondent, also appeared to be with above average score (mean=16.25 and std. dev. $=3.06$ ), which was ranked first to impact coffee supply performance as perceived by the respondents. The second important role of ECX, as rated by the respondent was provision of market information to be above the average score (mean $=11.25$ and $\mathrm{SD}=2.53$ ).

Similarly, the dimension of market development, price discovery and enabling competition as rated by the respondent their mean value were found that 13.8, 13.57 and 6.95 respectively. The dimension of market development, as rated by members, also appeared to be with above average score, which was ranked third to impact coffee performance as perceived by the respondents followed by price discovery and enabling competition.

\subsection{Regression Analysis and Interpretation of the Result}

The nature of data and review of relevant literature on related studies, linear regression was employed for this study to estimate the effects of explanatory variable on coffee supply and marketing performance. The dependent variable was the coffee supply and marketing performance measured by subjective measurement likert scale. Independent variable was the market information, enabling competition, market development, price discovery, storage and grading and facilitation of physical commodity trade.

Before formally present the regression linear regression have assumption that be fulfilled. As recommended by Gujerati (2004) meeting the assumption is necessarily to confirm that obtained data truly represent the true population. Accordingly, multi-collinearity, Hetroskedasticity, independent errors and linearity assumptions were tested and indicate no violation (see the appendex).

\subsubsection{Multiple Regression Result}

Linear regression was conducted to figure out the influence of explanatory variable (MI, EC, MD,PD,SG and FPT) of dependent variable(coffee supply performance). The significance level of 0.05 with $95 \%$ confidence interval was used. The reason for using multiple regression analysis was to assess the role/impact of the role variables of ECX on the coffee supply performance. The result of the regression analysis below: 
Table 3. ANOVA analysis of coffee supply performance

\begin{tabular}{l|l|l|l|l|l|l}
\hline Model & Sum of square & DF & Mean square & F & Sig & R-square \\
\hline Regression & .751 & 6 & 0.125 & 4.125 & 0.001 & 0.18 \\
\cline { 1 - 4 } Residual & 3.42 & 113 & 0.03 & & & \\
\cline { 1 - 4 } Total & 4.17 & 119 & & & & \\
\hline
\end{tabular}

Dependent Variable: Coffee supply performance

Predictors: (Constant), facilitation of physical trade, enabling competition, storage and grading, market development, price discovery, Market information

Source: survey result, 2020

The ANOVA table shows the overall significance/ acceptability of the model from a statistical perspective. The ANOVA table shows the sum of square of residual, regression and total associated with their degree of freedom.

From ANOVA table the most important one is F-statistics, which indicate the overall fitness of the model is significance. For this data, $\mathrm{F}$ is 4.125 , which is significant at $P<.001$. This result tells us that there is less than a $0.05 \%$ chance that an F-ratio this large would happen if the null hypothesis proposed about F- ratio were true. Therefore, it can be concluded that the regression model resulted in significantly better prediction of export performance and that the regression model overall predicted export performance significantly well.

\subsubsection{Regression Coefficient}

The study aim to identify the most important independent variable in contributing/influencing the dependent variable. Thus, the strength of each independent variable in influencing the dependent variable was investigated via standardized Beta coefficient. The result of the regression coefficient presented in table 4 below. The significance level of 0.05 with $95 \%$ confidence interval was used.

Table 4. Summary of the Coefficients

\begin{tabular}{l|l|l|l|l|l}
\hline \multirow{2}{*}{ Model } & \multicolumn{2}{|l|}{ Unstandardized Coefficients } & Standardized Coefficients & \multirow{2}{*}{ T } & \multirow{2}{*}{ Sig. } \\
\cline { 2 - 5 } & $\mathrm{B}$ & Std. error & Beta & & \\
\hline Constant & 2.583 & 0.147 & & 17.58 & 0.000 \\
\hline Market Information & 0.014 & 0.007 & 0.184 & 1.893 & 0.061 \\
\hline Enabling Competition & -0.008 & .008 & -.09 & -.959 & 0.34 \\
\hline Market Development & 0.011 & .006 & 0.159 & 1.81 & 0.073 \\
\hline Price Discovery & -.007 & 0.005 & -.119 & -1.279 & .204 \\
\hline Storage And Grading & .003 & .005 & .049 & .545 & .586 \\
\hline Facilitation Of Physical Trade & .022 & .005 & .359 & 4.057 & .000 \\
\hline
\end{tabular}

Dependent variable: coffee supply performance ( $95 \%$ confidence interval)

Source: Own computation, 2020

From table 4 , the value of constant from column B is 2.583 , which indicate that if all independent variable become zero the value of dependent variable (coffee supply performance) would be 2.583 .

Numbers below the column _ßeta' are the values for the regression coefficients for price discovery, facilitation of physical commodity trade, storage and grading, enabling competition Market development and market information provision. The standardized regression coefficient Beta $(\beta)$ is useful, because it allows us to compare the relative strength of each independent variable's relationship with the dependent variable (Fetene, 2019).

All independent variable have their expected sign except enabling competition and price discovery. Even though the sign of enabling competition and price discovery was found negative, their influence was insignificant. The other independent variable such as Market information, market development, storage and grading and facilitation of physical commodity trade were found positive. But in regression result Facilitation of physical commodity trade $(\mathrm{p}=0.000)$ were found significant at $1 \%$ level of significance, market information $(\mathrm{p}=0.061)$ and market development $(\mathrm{p}=0.073)$ were found significant at $10 \%$, the rest were found insignificant. Therefore, from the above result Facilitation of physical commodity trade $(\beta=0.359$, sig $=0.000)$ were found to be the most important factor of coffee supply performance followed by market information $(\beta=0.184$, sig=0.061) and market development $(\beta=0.159$, sig=0.073). 


\subsubsection{Discussion of the Result}

The objective of the study was to examine the role and challenge of ECX in coffee supply by measuring the core function ECX. Analyzing Market information, enabling competition, market development, price discovery, and storage and grading and facilitation of physical commodity trade influence on coffee supply and marketing performance was the main target of the study.

The descriptive analysis result indicated that the mean score of independent variable were above the mid-point for almost all variables except for storage and grading role of ECX. The average rating of storage and grading was scored 11.3, which is lower than the mid-point (12) and standard deviation 3.68. The average score of storage and grading role of ECX was also reported by Fetene (2019). On his study the role of ECX stimulating agricultural commodity export, indicated that grading and storage system of ECX had a problem of quality and advanced technology as a result of inadequate capital and inefficient infrastructure.

The research finding showed that the overall coffee supply performance as rated by the respondents has average score 23.14, which shows that there was positive and significant relationship between ECX and coffee supply and marketing performance.

The regression analysis result also indicated that there was a significant and positive relationship between Market Information, Market Development and facilitation of physical trade with coffee supply performance. This finding was found in line with the expectation and also supported by Anderson (2015), Bizualem et al(2018) and Fetene (2019).

The finding of the study found that there is positive and significant relationship between market information and coffee supply and marketing performance. The result was found that consistent with the expectation and the finding of Bizualem et al (2018) and Sisay (2019). The result indicate that ECX create a more reliable way to connect buyers and sellers in an efficient way to discover market prices, a way to level the playing platform by providing market information.

Similarly the relationship between market development and coffee supply and marketing performance was found to be positive and significant. The result is consistent and in line with the finding of Fetene (2019), which indicate that the provision of continuous market training and capacity building enhance the coffee supply and marketing performance. Provision of continuous training and capacity building, introduction of new product and service, assist the market with the use of information technology and communication enhances the performance of coffee supply and marketing.

With regard to the relationship between coffee supply performance and facilitation of physical commodity trade, the regression result indicated that there was significant positive relationship between these variables. The descriptive statistics also indicated that the role of ECX in facilitation of physical commodity trade, as rated by the respondent the first important role of ECX for its users. The finding was in line with the expectations and consistent with Muluken et al (2016) and Mekdes (2019). The finding indicate that ECX provide easily provide coffee product based on the client interest, has reduced default risk by making cash transaction and remote market can be easily accessible.

Even though ECX have contributed to coffee supply and marketing performance, it is not free from a problem. The finding of the research indicated that $55.83 \%$ of the respondent did not satisfy with the legal and regulatory service delivery system from ECX. The challenge are associated with service delivery system like grading system to test the quality of coffee was not uniform and biasedness one client from the other and wastage of time to test and low quality grading widely observed. ECX experts also indicate that absence of skilled man power, low government attention and capital shortage also another challenge in coffee marketing and supply. The finding supported by Mohammed (2015), his result indicate that the potential challenge were market abuse, increased cost of trading, liquidity issues, quality problem and unfair competition among traders.

\section{Summary, Conclusion and Recomindation}

\subsection{Summary of the Finding}

The study on hand examine the role and challenge of ECX in coffee marketing and supply by measuring the influence of ECX core function: market information, enabling competition, market development, price discovery, storage and grading and facilitation of physical commodity trade on coffee supply and marketing. Therefore the overall finding of the study summarized as follow:

The descriptive statistics result for ECX role on dependent variable (coffee supply performance) result showed that as rated by the respondent the mean score above the mid-point(18 if all respondent choose neutral) of the liker-scale was 23.14. the respondent also rate the core function of ECX namely: market information, enabling competition, market development, price discovery, storage and grading and facilitation of physical commodity.

The results of the descriptive statistics of the independent variables showed that, the mean scores facilitation of physical 
commodity trade, and market information provision were 16.25 and 11.21 which were the highest and second highest ratings respectively. The mean score of the enabling competition market development and price discovery was also above the mid-point rating with values of $6.95,13.8$ and 13.57 respectively. However, the ratings given by the respondent for storage and grading were found to be below mid-point with scores of 11.3. The result showed that ECX's facilitation of physical commodity trade service was given the highest score while the storage and grading service was given the least score by the respondents.

The multiple linear regression result indicate that three independent variable (Market information, market development and facilitation of physical commodity trade) were found to be significantly and positively influence the coffee supply and performance. Facilitation of physical commodity trade was significant at $1 \%$ while market information and market development were significant at $10 \%$.

Even though ECX have contributed to coffee supply and marketing performance, it is not free from a problem. The finding of the research indicated that $55.83 \%$ of the respondent did not satisfy with the legal and regulatory service delivery system from ECX. The challenge are associated with service delivery system like grading system to test the quality of coffee was not uniform and biasedness one client from the other and wastage of time to test and low quality grading widely observed. ECX experts also indicate that absence of skilled man power, low government attention and capital shortage also another challenge in coffee marketing and supply.

\subsection{Conclusion}

The general objective of the study was identified and analyzes the challenges and the role of Ethiopian commodity exchange on coffee supplies and marketing. In order to meet the general objective, survey was made. Questionnaire on dimensions of ECX's roles were developed and distributed to coffee exporting members and non-member direct traders of ECX.

Objective of the study has been attained. Regression analysis was conducted to verify the influence on market information, enabling competition, market development, price discovery, storage and grading and facilitation of physical commodity trade on coffee supply and marketing performance. The result indicated that market information, market development and facilitation of physical commodity trade have significant influence on coffee supply and performance. The services of ECX with regard to some core roles including storage and grading and price discovery was below mid-point which needs to be improved in order to stimulate coffee supply performance further.

The main role of ECX to influence coffee supply and performance would be the provision of storage and grading. On the other hand, this role of ECX was the least rated service by the respondents. Traders lack the confidence on the grade and quality of coffee they trade at ECX. Therefore, this implies that ECX should focus on improving this role dimension in order to impact coffee supply and marketing positively.

Market information and market development provision was found to be the second and the third strong influence on coffee supply and marketing. These implies that ECX should sustain its much-admired market information provision service quality and expand to the other fundamental roles like price discovery, enabling competition storage and grading in order to hugely impact coffee supply performance.

The provision of storage and grading role by ECX rated very least by the respondent. This indicated that storage and grading service should be improved to encourage the coffee supply and marketing performance. According to the respondent the main challenge associated mainly with the quality of storage and grading. The challenge are associated with service delivery system like grading system to test the quality of coffee was not uniform and biasedness one client from the other and wastage of time to test and low quality grading widely observed. ECX experts also indicate that absence of skilled man power, low government attention and capital shortage also another challenge in coffee marketing and supply.

\subsection{Recommendation}

Based on the finding and conclusion drown in the previous section the researcher forward the following recommendation:

Storage and grading were rated below the mid-point by the respondent, which show that the respondent were not happy with the storage and grading service of ECX. Therefore ECX should improve the service of storage and grading by introducing new technology and by maintaining transparent service. ECX should also build better warehouse management system in order to avoid wastage and quality deterioration.

The respondents also blame that ECX legal and regulatory service deliveries are not suitable to get the kind of service the client need. The procedures to get permission or service take long time and have difficult bureaucracy. Therefore, ECX should improve the legal service to attract their client. 
Biasedness in quality grading and delaying in shipment was also found that the other problem in ECX service delivery. Equal treatments of all ECX users improve the coffee supply and marketing performance. Therefore, ECX should have transparent and uniform grading system as well as better time management should also take into consideration.

Regulators of coffee marketing and export should control those market actors who create artificial shortages, gluts, and other unnecessary price distortions that do not reflect the realities of the market domestically and internationally.

Price discovery role of ECX have paramount importance on coffee supply and marketing performance. ECX should avoids shortages, gluts and other pricing distortions by creating better price signals and also inter-seasonal price variation should be minimized by providing better storage and warehouse management.

Market development is one core function of commodity exchanges now days. ECX should give attention to this service. Continuous capacity building and training tailored to coffee exporter members should be given. In addition, the company should think of starting international trade facilitation services for its members.

\subsection{Implication for Further Research}

Even though the study focuses on the role and challenge of ECX on coffee supply and marketing, it cannot be addressed by a single study. Therefore continuous research should work on ECX for proper identification of the role and challenge of ECX in all products. The study also conducted in a single product using cross-sectional data, Future researchers could undertake more in depth longitudinal study on other commodities. More over coffee supply and marketing may be affected by other variable in addition to market information, market development, enabling competition, price discovery, storage and grading and facilitation of physical commodity trade. Therefore, further research should be conducted by inclusion of other variable.

\section{References}

Abdurezack, H. (2010). Market efficiency of the Ethiopia commodity exchange: the case of export coffee trading, Ethiopia.

Alemayehu A. (2014). Coffee Production and Marketing in Ethiopia. European Journal of Business and Management, $6(37)$.

Ana, H. (2018). Determinants of market efficiency of commodity exchange: the case of Ethiopian Commodity Exchange. Master Thesis, Addis Ababa University.

Andersson, C., Bezabih, M., \& Mannberg, A. (2016). The Ethiopian Commodity Exchange and Spatial Price Dispersionll. Environment for Development Discussion paper series, EfD 16/02.

Bethelem, G. (2009). Critical Assessment of Ethiopian Commodity Exchange (ECX). Master Thesis, Addis Ababa University.

Bizualem, A., \& Saron, M. (2018). The Role of Ethiopian Commodity Exchange (ECX) in Crop Value Chain Development in Ethiopia. International Journal of Business and Economics Research, 7(6).

ECX. (2008). Directive of the Ethiopia commodity exchange authority, (2ndedn). Addis Ababa, Ethiopia.

Eleni, G. (2006). Getting markets right: the promise of emerging commodity exchanges, with reference to Ethiopia. The World's Commodities Exchanges, 62-66. Burgenstock: UNCTD and Swiss Futures and Options Association.

Fetene, A. (2019). The role of Ethiopian commodity exchange in stimulating agricultural commodities export, in case of coffee export. Master Thesis, Addis Ababa University.

Gabre-Madhin, Z., Eleni, \& Goggin, I. (2005). Does Ethiopia Need a Commodity Exchange: An Integrated Approach to Market Development, EDRI-ESSP Policy working paper.

Gebrekiros, G. (2011). Trading in Commodity Exchange and Challenges of Participants: The Case of Ethiopian Commodity Exchange. Master Thesis, Addis Ababa University.

Kothari, C. R. (2004). Research Methods and Techniques, 2nd revised edition. Jaipur (India): University of Rajasthan.

Mekdes, K. (2018). Determinants of market efficiency of Ethiopian commodity exchange: the case of sesame trade. Master Thesis, Addis Ababa University.

Meskerem, B. (2018). Factors Affecting the Market Efficiency of Ethiopian Commodity Exchange (ECX). Master Thesis, Addis Ababa University.

Ministry of Economic Development (MoFED). (2009). Successful Performance in the Agricultural Sector, Ethiopia Today: Bi-Monthly Magazine, January. Addis Ababa, Ethiopia. 
Mohammed, A. (2015). Ethiopia commodity exchange: Marketing prospects and challenges in focus. African Journal of Marketing Management, 9(3). https://doi.org/10.5897/AJMM2015.0458

Mulugeta, A. (2008). Ethiopia Commodity Exchange-Challenges And Opportunities Of Liquidity. Master Thesis, Addis Ababa University.

Muluken, A. (2016). The Contribution of Ethiopia Commodity Exchange for Promoting Exports of Agricultural Products. Journal of Economics and Sustainable Development, 7(9).

Rashid, S., Winter-Nelson, A., \& Garcia, P. (2010). Purpose and Potential of Commodity Exchanges in African Economies, IFPRI, Washington DC.

Rashid, S., Winter-Nelson, A., \& Garcia, P. (2010). Purpose and potential of commodity exchange inAfrican economies, IFPRI, Washington DC.

Rashid, S., Hernandez, M., Solomon, L., \& Tadesse, K. (2015). Institutions and Market Integration The Case of Coffee in the Ethiopian Commodity Exchange. International Food Policy Research Institute.

Rashid, S. (2015). Commodity Exchanges and Market Development: what have we learned, International Conference of Agricultural Economists. Milan, Italy. August 8-14.

Rashid, S., Winter-Nelson, A., \& Garcia, P. (2010). Purpose and Potential for Commodity Exchanges in African Economies. Paper prepared for the Fourth African Agricultural Markets Program Policy Symposium, Africa Agricultural Markets Program (AAMP). Lilongwe, Malawi. Sep.06-07, 2010.

Saunders, M., Lewis, P., \& Thornhill, A. (2012). Research methods for business students. Financial Times/ Prentice Hall, 6 edition.

Singh, L. (2006). Deceleration of industrial growth and rural industrialization strategy for Indian Punjab. MRPA no. 9

Sisay, E. (2019). Factors Affecting Market Efficiencyof Ethiopia Commodity Exchange. Master Thesis, Addis Ababa University.

Szenthe, A. (2019). Top Coffee Producing Countries. Retrieved from https:/www.worldatlas.com/articles/top-coffee-producing-countries.html

Tewabe, W. (2015). predicting the market status of coffee, pea beans and sesame: the case of Ethiopia Commodity Exchange. Master Thesis, Addis Ababa University.

Tsega, T. (2010). Ethiopian commodity exchange: connecting farmers to the market. Orebro University, Sweden. 


\section{Appendix}

Table 5. Multi-collinearity test

\begin{tabular}{llc}
\hline Variable & VIF & $1 /$ VIF \\
\hline Market Information(MI) & 1.30 & 0.76 \\
Enabling competition(EC) & 1.22 & 0.82 \\
Price discovery(PD) & 1.19 & 0.83 \\
Storage and Grading(SG) & 1.13 & 0.88 \\
Facilitation of Physical trade(FPT) & 1.08 & 0.92 \\
Market Development(MD) & 1.07 & 0.94 \\
Mean VIF & 1.16 & \\
Dependent variable: Coffee supply performance & &
\end{tabular}

Source: survey result, 2020

\section{Homoscedasticity}

Breusch-Pagan / Cook-Weisberg test for heteroskedasticity

Ho: Constant variance, $\quad \mathrm{H}_{1}$ : not $\mathrm{H}_{\mathrm{O}}$

Variables: fitted values of CS(coffee supply performance)

$\begin{array}{llr}\operatorname{ch} 2(1) & = & 2.16 \\ \text { Prob }>\text { chi2 } & = & 0.1413\end{array}$

Source: survey result, 2020

\section{Copyrights}

Copyright for this article is retained by the author(s), with first publication rights granted to the journal.

This is an open-access article distributed under the terms and conditions of the Creative Commons Attribution license which permits unrestricted use, distribution, and reproduction in any medium, provided the original work is properly cited. 